\title{
Post Fever Uveoretinal Manifestations in an Immunocompetent Individual
}

\author{
Authors: \\ *Srinivasan Sanjay, Sameeksha Agrawal, Padmamalini Mahendradas, \\ Ankush Kawali, Aditi Gupta, Rohit Shetty \\ Narayana Nethralaya, Bengaluru, India \\ *Correspondence to sanjaygroup24@gmail.com \\ Received: \\ 10.04 .20 \\ Accepted: \\ 18.05 .20 \\ Keywords: \\ Choroiditis, chikungunya, dengue, macular oedema, maculopathy, multifocal retinitis, \\ neuroretinitis, retinitis, rickettsiosis, typhoid, West Nile. \\ Citation: \\ EMJ Allergy Immunol. 2020;5[1]:91-105.
}

\section{Abstract}

Background: Post fever uveoretinal sequelae (PFURS) are the various uveoretinal manifestations seen after a systemic febrile illness in an immunocompetent individual caused by bacteria, viruses, and protozoa. These may be the result of a direct invasion by the pathogen or by indirect mechanism mediated through immune mechanisms.

Method: The authors aim to review the ocular manifestations, utility of relevant diagnostic tests, management, and prognosis of PFURS. A comprehensive literature search was conducted on PubMed and Google Scholar databases with the search words "retinitis", "choroiditis", "neuroretinitis", "macular edema”, "maculopathy", "multifocal retinitis", "chikungunya”, "dengue”, "West Nile”, "typhoid”, and "rickettsiosis". Only articles published or translated into English language were considered. The key data were extracted, evaluated, and combined.

Results: The authors search yielded 95 articles for the period between 1986 and May 2020. Painless blurring of vision was the most common symptom. Patients can have varied posterior segment manifestations, including vitritis, focal and multifocal patches of retinitis which could be unilateral or bilateral, optic nerve involvement, serous detachment at the macula, macular oedema, and localised involvement of the retinal vessels in the form of beading of the vessel wall, tortuosity, and perivascular sheathing.

Conclusion: PFURS presents with a similar morphological pattern irrespective of the aetiology and follows a preset natural course before resolution. Treatment may or may not be required. Treating physicians need to be aware of this important ophthalmic condition even after complete resolution of fever.

\section{INTRODUCTION}

Post fever uveoretinal sequelae (PFURS) is used for describing the various uveoretinal manifestations seen 2-4 weeks after a systemic

febrile illness in an immunocompetent individual with positive serology for bacteria, viruses, or protozoa. These manifestations may be the result of a direct invasion by the pathogen or by indirect mechanism mediated 
through immune mechanisms. ${ }^{1}$ Ocular symptoms include sudden, painless diminution of vision, black dots, flashes of light, loss of one-half of visual field, and central black outs. Patients can have varied uveoretinal manifestations including solitary and multifocal patches of retinitis, serous detachment at the macula, macular oedema, and localised/generalised involvement of the retinal vessels in the form of beading of the vessel wall, tortuosity, and perivascular sheathing and optic nerve involvement. ${ }^{1,2}$ Irrespective of the cause of the fever, clinical presentations of cases are similar with predominant signs at the posterior pole of the retina and a favourable response to steroids may suggest a possible immunological basis for this condition. ${ }^{1-7}$

Epidemic retinitis (ER) is a retinitis post-febrile illness commonly caused by Rickettsia, dengue, chikungunya, West Nile virus (WNV), and several other as yet unknown organisms, generally seen in tropical countries. ${ }^{2,8,9}$ ER has been previously described by different authors as "postfever retinitis" or "acute multifocal retinitis."10,11 Herein, various pathogens implicated in PFURS are discussed. Table 1 summarises various studies in medical literature. ${ }^{4,5,2-30}$

\section{VIRAL}

Chikungunya, dengue, and Zika viruses have emerged as increasingly important arboviruses that cause ophthalmic manifestations. The global expansion of these arboviruses was preceded by the global spread of their vectors. These arboviruses have common and very similar symptoms such as fever, skin rashes, malaise, headache, neutropenia, and lymphopenia. ${ }^{31}$

\section{Dengue}

Dengue maculopathy is a common posterior segment condition and its incidence may correlate with the severity of systemic disease. ${ }^{12}$ Common ophthalmic manifestations include subconjunctival, vitreous, and retinal haemorrhages; anterior and posterior uveitis; optic neuritis; and maculopathies such as foveolitis, haemorrhage, and oedema. Main symptoms include blurring of vision, scotomata, metamorphopsia, and floaters. ${ }^{12}$

Symptoms of dengue maculopathy start at a mean of 6.9 days after the onset of fever.
Poorer visual acuity may be seen in patients with macular oedema or foveolitis, and this correlates with the severity of macular oedema. There may be presence of well-defined, yellowish subretinal lesions in the macula along with retinal striae radiating around the fovea (foveolitis). These lesions may represent disruption of photoreceptors, the outer neurosensory retina, and the inner segment/outer segment (IS/OS) junction, along with dot and blot and macular haemorrhages which corresponds to areas of scotomata. ${ }^{32-36}$

The presence of foveolitis in patients with maculopathy was 7\%. In the study by Pang and Loh, ${ }^{37}$ four out of six patients had bilateral disease. Some eyes had concurrent findings of superior temporal branch vein occlusion and macular oedema, while some had associated foveolitis and vasculitis suggestive of an inflammatory pathophysiology. Haemorrhagic retinopathy associated with dengue haemorrhagic fever is related to the induced thrombocytopenia. The onset of visual symptoms is usually observed within 1 day from the resolution of fever and at the nadir of the thrombocytopenia. ${ }^{37}$ Secondary dengue infection may manifest as retinitis with signs of microvascular occlusions in the retina. ${ }^{13}$

Changes such as anterior uveitis, exudative maculopathy, choroidal effusion, Roth spots, vasculitis, exudative retinal detachment, and panophthalmitis are rare.' Mean complement C3 levels were lower in subjects with dengue maculopathy than in those without. The appearance of maculopathy 1 week after onset of fever suggests that dengue maculopathy is the result of an immune-mediated process and not a direct consequence of viral invasion of ocular tissue. ${ }^{12}$ Acute macular neuroretinopathy (AMN) has been recently reported to be an unusual manifestation of dengue maculopathy. ${ }^{38,39}$ AMN presents with hyper-reflectivity of the outer retina (outer plexiform layer and outer nuclear layer), and disruption of ellipsoid zone, external limiting membrane, and interdigitation zone. ${ }^{39}$

Fundus fluorescein angiography is a useful imaging modality to determine the extent and severity of retinal manifestations such as maculopathy and retinal vasculitis. Foveolitis appears as retinal pigment epithelial hyperfluorescence that appears in the early phase and persists till the late phase. 


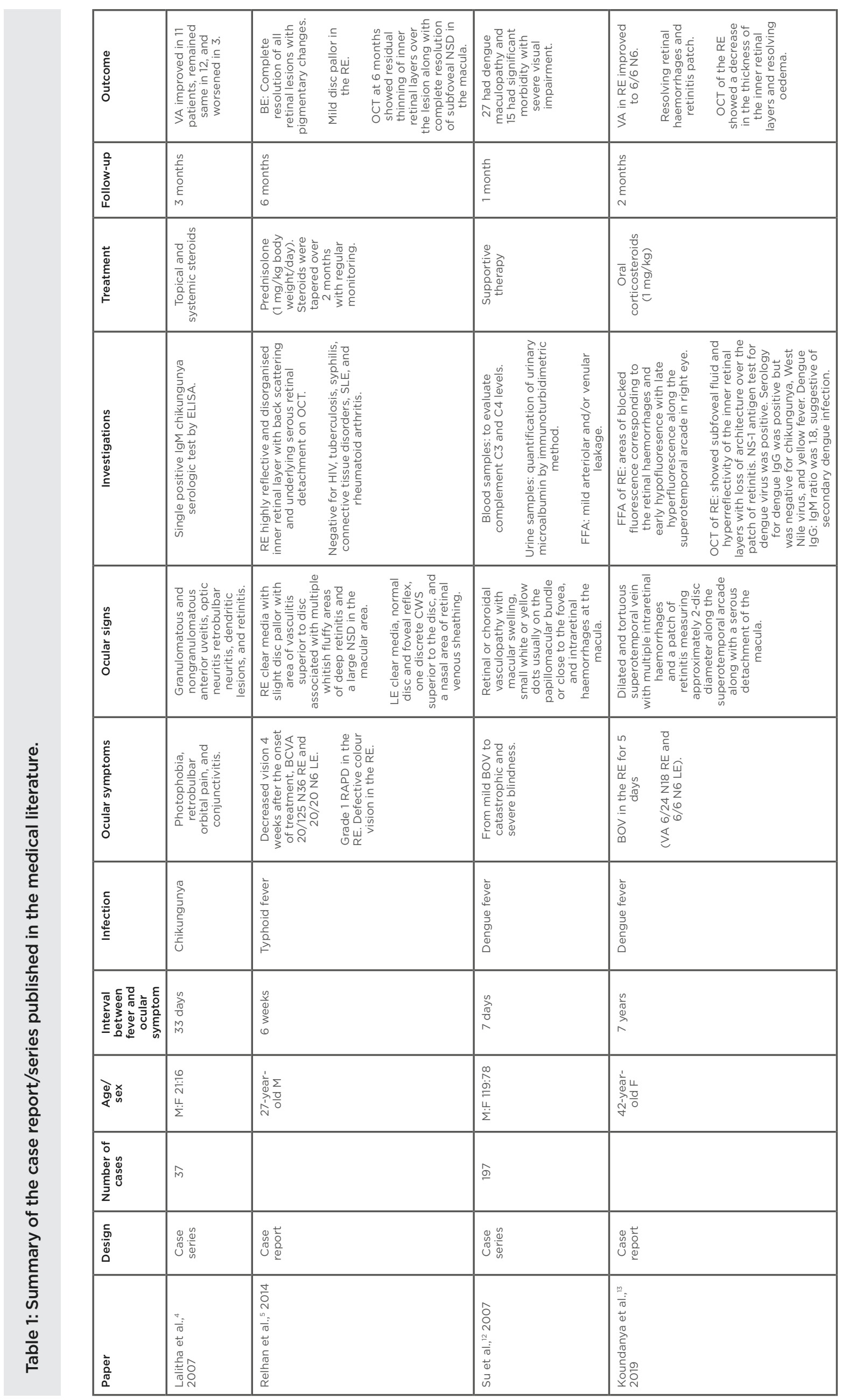




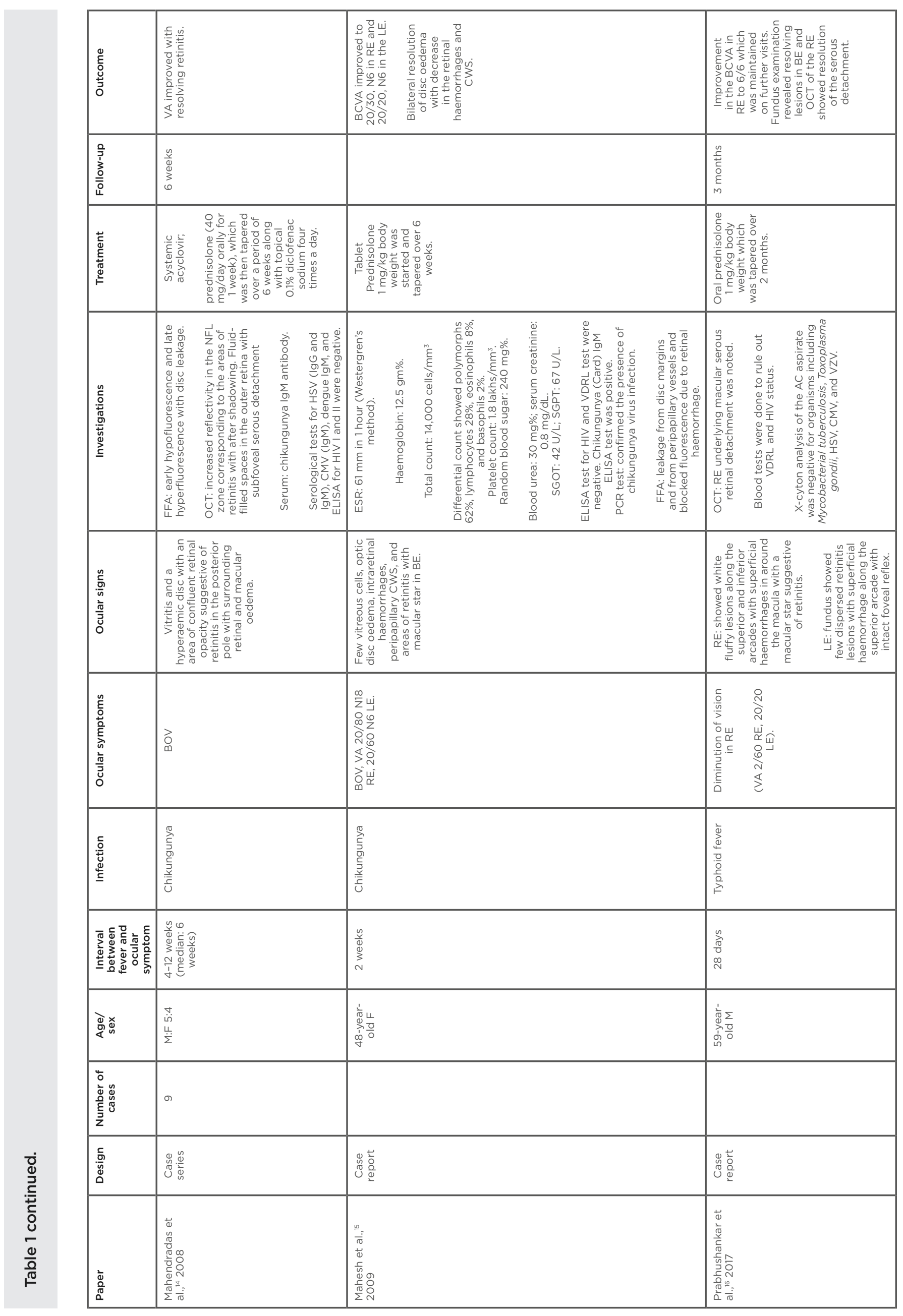




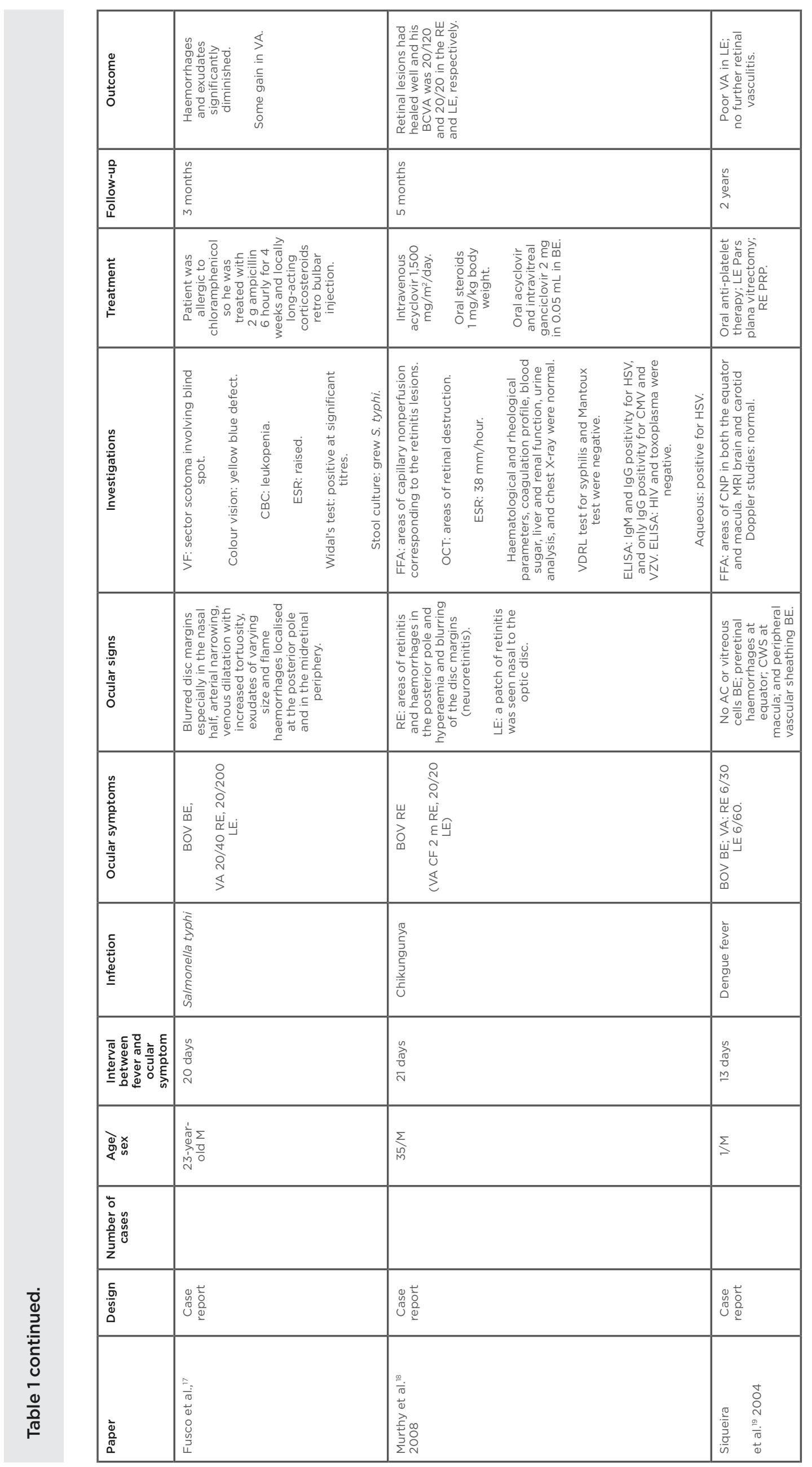




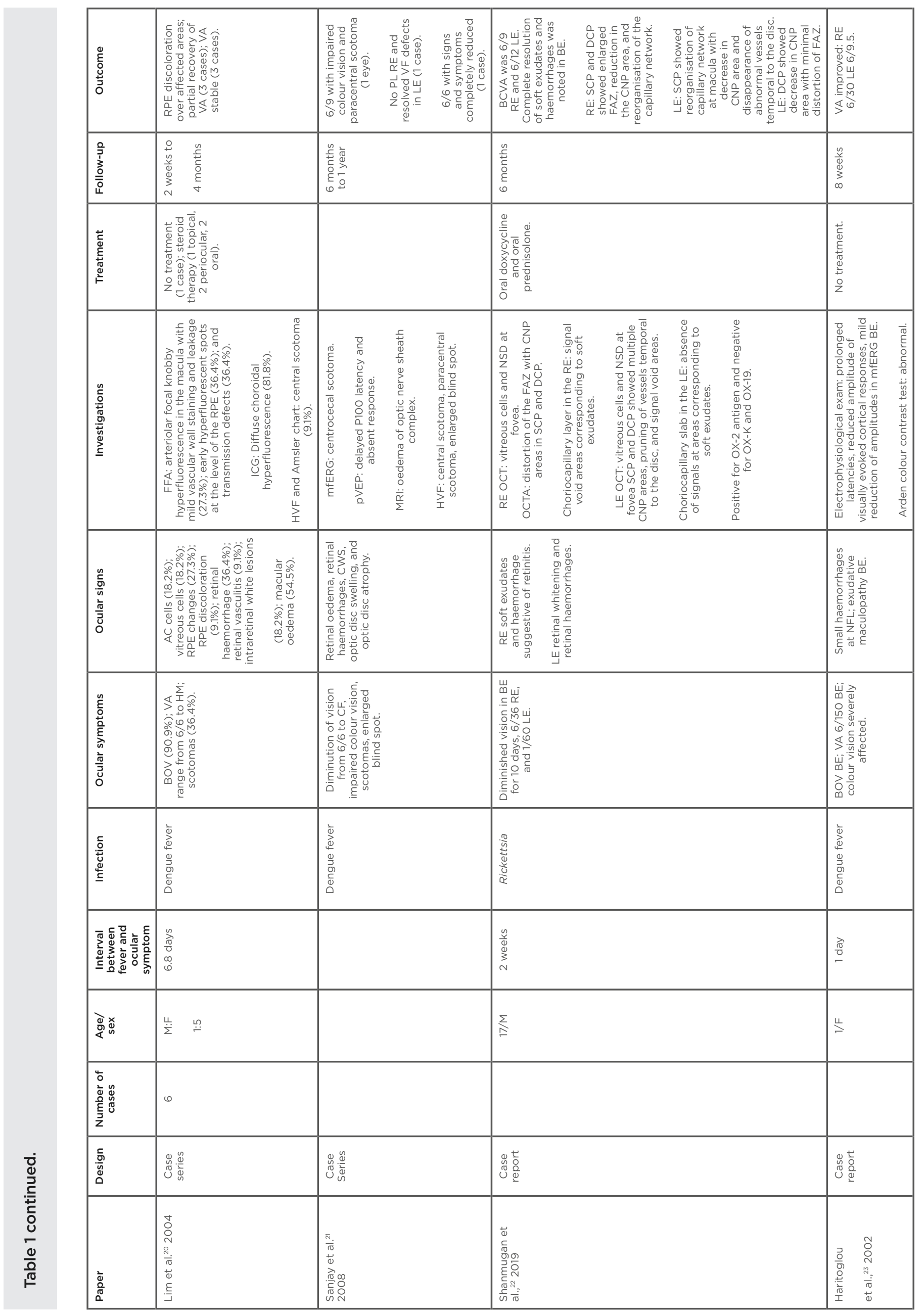




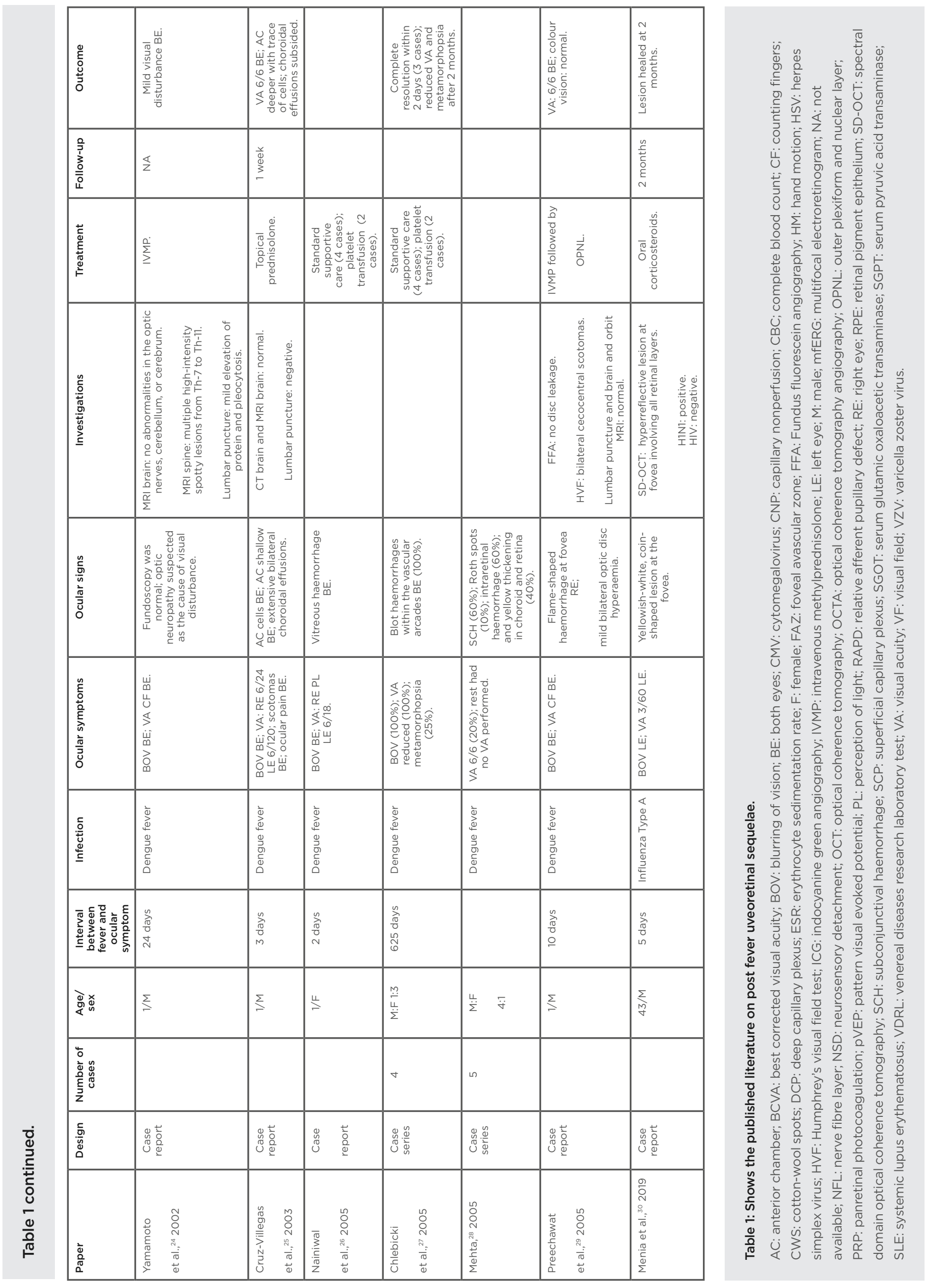


There may be presence of macular periphlebitis and occlusion. Common findings include disc leakage, arteriolar leakage, and macular oedema. Indocyanine green angiography may show presence of hypocyanescent spots suggestive of the involvement of choriocapillaris and the retinal pigment epithelium. ${ }^{39-41}$

\section{Chikungunya Virus}

Chikungunya fever is a common arthropod-borne viral illness that commonly affects Asian countries and Pacific islands. Epidemics of chikungunya have recently been reported from several Asian countries, such as India. ${ }^{2,42-44}$ Ophthalmic manifestations may be unilateral or bilateral. Retinitis presents between 2 and 4 weeks after febrile period of systemic disease. ${ }^{33}$ Chikungunya retinitis can be differentiated from herpetic retinitis by less vitreous reaction and confluent posterior pole retinitis, whereas acute retinal necrosis is characterised by intense vitritis and peripheral multifocal or disseminated retinitis. ${ }^{45,46}$ It can also simulate WNV retinitis, therefore, it is important to assess systemic symptoms to differentiate the aetiology of the manifestation. ${ }^{47}$ All these patients have a good visual outcome with almost total recovery within 10-12 weeks. $^{9}$

It is presumed that an immune dysregulation, superantigen induction, hypersensitivity reaction, and molecular mimicry between stimulating virus-derived antigens and normal or altered host tissue proteins may be the cause of the optic nerve damage, while some hypothesise that ocular manifestations associated with chikungunya fever may be an immune-mediated process-like production of autoantibody rather than a direct viral infection. ${ }^{4}$

The authors' experience shows that anterior uveitis and retinitis are the most common ocular manifestations associated with chikungunya, with a typically benign clinical course. ${ }^{14}$ However, longterm sequelae of the retinitis revealed thinning of the inner retinal layers.

Bilateral neuroretinitis associated with chikungunya infection has been reported..$^{15}$ Other viral infections caused by measles, influenza, Epstein-Barr, dengue, and Rift valley fever viruses can also present with neuroretinitis occurring subsequent to an acute viral systemic illness. Vishwanath et al.' showed that a patient who was positive for IgM chikungunya virus had bilateral anterior nongranulomatous uveitis and retinitis with optic nerve involvement in one eye showed a favourable response to oral steroids.

\section{Zika Virus}

Zika virus ocular manifestations are usually mild, such as nonpurulent conjunctivitis in adults, though it may be linked to uveitis, maculopathy, and hypertensive iridocyclitis later. ${ }^{48}$ Miranda et al. ${ }^{49}$ described ocular findings in three patients with microcephaly and a presumed Zika virus infection. All six eyes had pigmentary maculopathy ranging from mild to pronounced. Some showed well-delineated macular chorioretinal atrophy with a hyperpigmented ring, while others had vascular tortuosity and pronounced early termination of the retinal vasculature, washed-out peripheral retina with a hypolucent spot, and scattered subretinal haemorrhages external to the macula on photographic evaluation. One characteristic finding seen was peripheral pigmentary changes and clustered atrophic lesions resembling grouped congenital albinotic spots (polar bear tracks). ${ }^{49}$

Some other studies have shown macular changes (thick pigment spots and/or chorioretinal atrophy) and optic nerve abnormalities (double ring hypoplasia, pallor, and/or increased cupdisc ratio). ${ }^{50}$ Another case report described a patient with strongly positive value on a serum plaque reduction neutralisation technique with macular retinal pigment epithelium changes with a grey annulus around the fovea on posterior segment examination and disruption of outer retinal and retinal pigment epithelium integrity in the central macula evidenced on optical coherence tomography. ${ }^{51}$

The first signs of congenital ocular involvement related to Zika virus were reported in January 2016 in three Brazilian children with microcephaly who were born to a mother who had been infected with the virus during pregnancy. ${ }^{50,52,53}$ The presence of these complications was substantiated by Freitas et al. $^{54}$ who identified that among 29 newborns with microcephaly, 10 children had ocular abnormalities. The lesions consisted of zones of chorioretinal pigmentation or atrophy and bilateral in $70 \%$ of cases. Optic nerve changes described were hypoplasia, disc pallor, or large cups. ${ }^{54}$ These abnormalities 
were increasingly frequent with smaller cranial circumference and if the symptoms of Zika virus infection occurred during the first trimester of pregnancy. ${ }^{55}$ Also reported were atrophic and pigmented lesions resembling torpedo maculopathy, abnormal retinal vascular patterns, retinal haemorrhages, and lesions of the iris (coloboma) or lens (subluxation). ${ }^{54-56}$

\section{Ebola Virus}

Shantha et al. ${ }^{57}$ have summarised a number of reports about the ophthalmic sequelae of Ebola virus disease in the recent and past outbreaks. The prevalence of uveitis has ranged from $18 \%$ to $34 \%$ of survivors; in their own series (from the recent outbreak in West Africa), more than onethird of those with uveitis were blind. In addition to cases of posterior uveitis, which can result in the retinal lesions described by Steptoe et al.,58,59 there were cases of isolated anterior uveitis and intermediate uveitis. Other ophthalmic conditions included optic neuropathy and other neuroophthalmic problems in some, ${ }^{60,61}$ while others progressed to phthisis.

As many as $20 \%$ of convalescent patients, who may be asymptomatic for up to 2 months, develop hypertensive uveitis characterised by ocular pain, photophobia, hyperlacrimation, foreign body sensation, red eye, and progressive visual loss. ${ }^{62}$

Ebola retinal lesions varied in size and shape, but distinctive linear borders with sharp angulations were characteristic. Multimodal imaging features varied according to severity and extent of retinal structures involved. Lesions appeared light grey on fundus photography and were predominantly nonpigmented. ${ }^{58}$

\section{Influenza A (H1N1) Virus}

Studies show nonconfluent cotton wool spots in H1N1 representing milder versions of ischaemic retinopathy. Visual acuity normalised over several months in some, whereas patients with bilateral peripapillary cotton wool spots took over 3 weeks to resolve. ${ }^{63,64}$

Ashfaq et al. ${ }^{65}$ reported a case series of acute macular neuroretinopathy associated with virologically confirmed acute influenza virus Infection. Ocular symptoms range from pain, redness, and decreased visual acuity to uveal effusion syndrome and orbital inflammatory syndrome. Vision loss may also be caused by simultaneous retinal and lateral geniculate body infarction. ${ }^{66}$

\section{West Nile Virus}

Posterior segment manifestation of WNV include chorioretinitis or only retinitis, anterior uveitis, retinal occlusive vasculitis in which arterial involvement is greater than venous involvement, optic neuritis, and congenital chorioretinal scarring optic neuropathies. ${ }^{67,68}$ The characteristic feature of WNV chorioretinitis is a curvilinear clustering of whitish-yellow chorioretinal scars with a 'targetlike' appearance, following the course of the retinal nerve fibres. ${ }^{69}$ Sivakumar et al. $^{3}$ reported a case series of WNV retinitis from South India which did not follow the classical pattern of WNV infection. Fundus examination revealed discrete, superficial, white retinitis; arteritis; phlebitis; and retinal haemorrhages with or without macular star. The fundus fluorescein angiography revealed areas of retinal inflammation with indistinct borders, vascular and optic disc leakage, vessel wall staining, or capillary nonperfusion.

\section{Coronavirus}

The most recent entrant to this list is the severe acute respiratory syndrome coronavirus-2 (SARS-CoV-2) which was first detected in December 2019 in Wuhan, China. ${ }^{70}$ This outbreak was suspected when numerous unexplained pneumonia cases occurred. It has been established that infectious droplets and body fluids can easily contaminate the human conjunctival epithelium. Respiratory viruses are capable of inducing ocular complications in infected patients, which then leads to respiratory infection. SARS-CoV-2 coronavirus disease-2019 (COVID-19) is predominantly transmitted through direct or indirect contact with mucous membranes in the eyes, mouth, or nose. The fact that exposed mucous membranes and unprotected eyes increased the risk of COVID-19 transmission suggests that exposure of unprotected eyes to SARS-CoV-2 could cause acute respiratory infection. Posterior segment manifestations were recently reported by Marinho et al. ${ }^{71}$ They found hyper-reflective lesions at the level of ganglion cell and inner plexiform layers more prominently at the papillomacular bundle in both eyes and subtle cotton wool spots and microhaemorrhages along the retinal arcade. 


\section{BACTERIAL}

\section{Typhoid}

In addition to causing enteric fever, septicaemia, gastroenteritis, and vasculitis, Salmonella typhi can affect the eye either by direct infection or rarely by immune-mediated mechanisms. DukeElder and Perkins $^{72}$ reported typhoid-related uveal complications including iritis, retinal haemorrhage, choroiditis endophthalmitis, panophthalmitis, vasculitis, and retinitis with macular neurosensory detachment post-typhoid fever.

Salmonella spp., including enteritidis, typhimurium, and choleraesuis, have been isolated from aqueous and vitreous samples in patients with endogenous endophthalmitis. ${ }^{73}$

Other posterior segment manifestations reported are frosted branch angiitis; bilateral chorioretinitis with stellate maculopathy; vitritis; multifocal patches of retinitis; macular oedema; disc involvement in the form of hyperaemia, oedema or sphincter haemorrhages; and localised retinal vascular sheathing. ${ }^{74}$ Endogenous endophthalmitis is a rare complication of salmonella infections occurring in immunocompromised patients. ${ }^{75}$ Patients with bilateral confluent retinitis had significantly high Widal titres. ${ }^{76}$ Bilateral retinitis following typhoid fever was also reported.16,77 Multifocal choroiditis following simultaneous hepatitis A, typhoid fever, and yellow fever vaccination is an inflammatory disease characterised by multiple, small, yellow fundus lesions and vitreous inflammation which is because of the involvement of the eye which may be a result of direct invasion or immune-mediated phenomenon. ${ }^{75}$

\section{Rickettsioses}

The spotted fever group includes Mediterranean spotted fever (MSF), Rocky Mountain spotted fever, and numerous other rickettsioses. MSF, also called 'boutonneuse' fever or tick-borne rickettsiosis, is caused by the organism Rickettsia conorii and is prevalent in Mediterranean countries and Central Asia, including India. ${ }^{78}$ Indian tick typhus and epidemic typhus could be the common subtypes seen in the South Indian population. ${ }^{7}$
Ocular involvement includes anterior segment features such as conjunctivitis, keratitis, and anterior uveitis. Retinitis, retinal vascular involvement, and optic disc changes are the most common ocular findings presenting with white retinal lesions, typically adjacent to retinal vessels and associated mild or moderate vitreous inflammation in $30 \%$ of patients with acute MSF. The cotton wool spot-like retinal lesions could result from intraretinal multiplication of organisms or alternatively as a result of immune complex deposition along retinal vessels. ${ }^{78,79}$ Fluorescein angiography showed early hypofluorescence and late staining of large acute white retinal lesions and isofluorescence or moderate hypofluorescence of small active retinal lesions throughout the whole phase of dye transit. Optical coherence tomography shows serous retinal detachment and large foci of rickettsial retinitis which predominantly involves the inner retina. ${ }^{78,79}$

Balasundaram et al. ${ }^{7}$ described a case series of patients with serologically proven Indian tick typhus ( $R$. conorii) infection, in whom multifocal retinitis predominantly involved the posterior pole and macular involvement in the form of serous macular detachment or macular hard exudates. Doxycycline along with oral corticosteroids was effective in treating the condition. A case of bilateral rickettsial retinitis was reported which worsened on systemic steroids and responded dramatically to therapy with oral doxycycline and steroid taper. ${ }^{80}$ The authors' experience with 19 eyes of 10 patients with retinitis on the posterior pole with a recent history of fever with or without skin rash and a positive Weil-Felix test suggested a presumed rickettsial aetiology. ${ }^{8}$

\section{PARASITE}

\section{Malaria}

Malaria retinopathy is a condition which is a defining characteristic of cerebral malaria as a result of Plasmodium falciparum infection. This condition is usually bilateral and may be associated with papilloedema, patchy retinal whitening, focal changes in vessel colour, and white-centred haemorrhages. ${ }^{81}$

However, there have been studies that showed patients who were positive for malaria parasite, 
Table 2: Summary of post fever uveoretinal sequalae as reported in published medical literature.

\begin{tabular}{|c|c|c|c|c|c|}
\hline & Symptoms & Signs & OCT & FFA & Treatment \\
\hline Dengue & $\begin{array}{l}\text { Blurring of vision } \\
\text { Scotoma } \\
\text { Metamorphopsia } \\
\text { Floaters }{ }^{45}\end{array}$ & $\begin{array}{l}\text { Vitreous and retinal haemorrhages } \\
\text { Posterior uveitis } \\
\text { Optic neuritis and maculopathy } \\
\text { Foveolitis }{ }^{45} \\
\text { Macular oedema }{ }^{15} \\
\text { RAPD } \\
\text { Vessel engorgement } \\
\text { Colour vision impairment } \\
\text { Loss of contrast sensitivity }{ }^{82} \\
\text { Intraretinal cystoid spaces } \\
\text { Perifoveal telangiectasia } \\
\text { Intraretinal haemorrhages }{ }^{19,20} \\
\text { Cotton wool spots } \\
\text { Microaneurysm }{ }^{19,20} \\
\text { Retinitis } \\
\text { Chorioretinitis } \\
\text { Neuroretinitis } \\
\text { Roth spots } \\
\text { Pan retinal vasculitis } \\
\text { Exudative RD }{ }^{82} \\
\text { Optic neuropathy }\end{array}$ & $\begin{array}{l}\text { Three patterns } \\
\text { of maculopathy: } \\
\text { diffuse retinal } \\
\text { thickening, CME, and } \\
\text { foveolitis }{ }^{32-36} \\
\text { Diffuse retinal } \\
\text { thickening: increased } \\
\text { central or paracentral } \\
\text { fovea thickness } \\
\text { associated with loss } \\
\text { of foveal dimple. } \\
\text { CME: large intraretinal } \\
\text { ovoid areas of } \\
\text { hyporeflectivity } \\
\text { with reflective septa } \\
\text { separating the cystoid } \\
\text { cavities. } \\
\text { Foveolitis: area of } \\
\text { thickening and high } \\
\text { reflectivity at the } \\
\text { subfoveal outer retina } \\
\text { layer. There may be } \\
\text { a tented elevation } \\
\text { and separation of the } \\
\text { highly reflective layer } \\
\text { with accumulation } \\
\text { of subretinal fluid. } \\
\text { Serial OcT imaging } \\
\text { demonstrate } \\
\text { spontaneous } \\
\text { rapid resolution of } \\
\text { oedema. }{ }^{12,38,40,41} \\
\text { of }\end{array}$ & $\begin{array}{c}\text { Arteriolar leakage } \\
\text { Macular oedema } \\
\text { Disc leakage } \\
\text { Choroidal } \\
\text { hyperfluoresence } \\
\text { Blocked fluorescence or } \\
\text { capillary non-perfusion } \\
\text { Retinal vasculitis }\end{array}$ & $\begin{array}{l}\text { Oral corticosteroids } \\
\text { (1 mg/kg) } \\
\text { Standard } \\
\text { supportive }{ }^{13} \text { care }^{12}\end{array}$ \\
\hline Chikungunya & $\begin{array}{l}\text { Decreased vision } \\
\text { Central scotoma } \\
\text { Peripheral field } \\
\text { defect } \\
\text { Colour vision } \\
\text { defect }^{84}\end{array}$ & $\begin{array}{c}\text { Intraretinal haemorrhages } \text { hem }^{2,33,44,78} \\
\text { Choroiditis } \\
\text { Retinitis } \\
\text { Optic neuritis }{ }^{18} \\
\text { Neuroretinitis, and retrobulbar } \\
\text { neuritis } \\
\text { Panuveitis } \\
\text { Retinal oedema and opacification } \\
\text { Mild vitritis } \\
\text { Disc oedema } \\
\text { Severe inflammation may result in } \\
\text { exudative retinal detachment } \\
\text { Retinal vasculitis } \\
\text { Intermediate uveitis }\end{array}$ & $\begin{array}{l}\text { Focal and multifocal } \\
\text { patches of retinitis } \\
\text { Macular oedema } \\
\text { Serous detachment } \\
\text { at the macula and } \\
\text { localised involvement } \\
\text { of the retinal vessel } \\
\text { Hyperreflectivity of } \\
\text { OPL, ONL, disruption } \\
\text { of ellipsoid zone, ELM, } \\
\text { and interdigitation } \\
\text { zone }\end{array}$ & $\begin{array}{c}\text { Early hyperfluorescence } \\
\text { followed by late } \\
\text { hyperfluorescence } \\
\text { corresponding to area } \\
\text { of retinitis }\end{array}$ & $\begin{array}{c}\text { Systemic acyclovir } \\
\text { and prednisolone } \\
\text { (40 mg/day orally } \\
\text { for } 1 \text { week) tapered } \\
\text { over a period of } 6 \\
\text { weeks } \\
\text { Topical } 0.1 \% \\
\text { diclofenac } 14 \text { sodium } \\
\text { four times a day }\end{array}$ \\
\hline Zika & $\begin{array}{l}\text { Decreased vision } \\
\text { Redness } \\
\text { Nonpurulent } \\
\text { conjunctivitis }^{86}\end{array}$ & $\begin{array}{l}\text { Chorioretinal atrophy }{ }^{52} \\
\text { Macular changes (thick pigment } \\
\text { spots and/or chorioretinal atrophy } \\
\text { with hyperpigmented ring) } \\
\text { Optic nerve abnormalities (double } \\
\text { ring hypoplasia, pallor, increased } \\
\text { cup-disc ratio) }{ }^{50,52,87} \\
\text { Macular pigment mottling } \\
\text { Neuroretinal atrophy with macular } \\
\text { involvement } \\
\text { Iris coloboma } \\
\text { Changes in retinal vasculature } \\
\text { (congenital) }\end{array}$ & $\begin{array}{l}\text { Nodular elevations } \\
\text { in the outer retinal } \\
\text { layers } \\
\text { Interruption of the } \\
\text { outer retinal layers } \\
\text { and an irregularity } \\
\text { of the retinal } \\
\text { pigment epithelial } \\
\text { thickness }\end{array}$ & $\begin{array}{l}\text { Hypofluorescent in the } \\
\text { centre of the macula } \\
\text { Hyperfluorescent in the } \\
\text { surrounding areas } \\
\text { 50,51 }\end{array}$ & $\begin{array}{c}\text { Intravenous } \\
\text { methylprednisolone } \\
\text { for } 3 \text { days, followed } \\
\text { by oral prednisolone } \\
\text { for } 11 \text { days }{ }^{56}\end{array}$ \\
\hline Ebola & $\begin{array}{l}\text { Ocular pain } \\
\text { Photophobia } \\
\text { Hyperlacrimation } \\
\text { Foreign body } \\
\text { sensation } \\
\text { Red eye } \\
\text { Progressive visual } \\
\text { loss }^{61,62,88}\end{array}$ & $\begin{array}{c}\text { Vitreous opacities } \\
\text { Vitritis } \\
\text { Multiple chorioretinal scars with } \\
\text { hypopigmented halos } \\
\text { Small intraretinal haemorrhages } \\
\text { Posterior uveitis } \\
\text { Panuveitis } \\
\text { P1,62 }\end{array}$ & $\begin{array}{l}\text { Multiple vertical } \\
\text { discontinuities of } \\
\text { the ellipsoid zone } \\
\text { and interdigitation } \\
\text { zone with overlying } \\
\text { V-shaped increased } \\
\text { reflectance of the } \\
\text { ONL }^{58}\end{array}$ & & $\begin{array}{l}\text { Antiviral therapy } \\
\text { with favipiravir }{ }^{57,60} \\
\text { Periocular } \\
\text { triamcinolone } \\
\text { acetonide injection } \\
\text { (40 mg/mL) } \\
\text { Oral corticosteroids }\end{array}$ \\
\hline
\end{tabular}


Table 2 continued.

\begin{tabular}{|c|c|c|c|c|c|}
\hline & Symptoms & Signs & OCT & FFA & Treatment \\
\hline $\begin{array}{l}\text { H1N1 } \\
\text { (influenza A) }\end{array}$ & $\begin{array}{c}\text { Severe bilateral } \\
\text { vision loss to } \\
\text { the level of light } \\
\text { perception within } \\
24 \text { hours of having } \\
\text { fever and myalgias } \\
\text { Pain } \\
\text { Redness }\end{array}$ & $\begin{array}{c}\text { Confluent ischaemic retinopathy } \\
\text { Confluent and sharp-bordered } \\
\text { ischemic retinal white patches } \\
\text { Dense anterior chamber } \\
\text { inflammation } \\
\text { Vitritis } \\
\text { Peripheral retinal necrosis } \\
\text { Choroiditis } \\
\text { Submacular haemorrhages } \\
\text { Macular oedema } \\
\text { Neuroretinitis } \\
\text { Vaso-occlusive retinal vasculitis }{ }^{90} \\
\text { Frosted branch angiitis } \\
\text { Exudative retinal detachment }{ }^{91} \\
\text { Optic neuritis }\end{array}$ & $\begin{array}{l}\text { Inner retinal } \\
\text { thickening and } \\
\text { hyperreflectivity } \\
\text { in both eyes; outer } \\
\text { retinal layers were } \\
\text { relatively spared }\end{array}$ & $\begin{array}{l}\text { Arteriolar occlusions } \\
\text { posteriorly with } \\
\text { minimal late leakage } \\
\text { and no retinal vascular } \\
\text { abnormalities in the } \\
\text { periphery }\end{array}$ & Oral corticosteroids ${ }^{30}$ \\
\hline $\begin{array}{l}\text { West Nile } \\
\text { fever }\end{array}$ & $\begin{array}{c}\text { Blurring of vision } \\
\text { Visual field defects } \\
\text { Floaters } \\
\text { Diplopia } \\
\text { Redness } \\
\text { Pain }{ }^{69}\end{array}$ & $\begin{array}{c}\text { Active chorioretinal lesions appear as } \\
\text { circular, deep, creamy lesions } \\
\text { Inactive chorioretinal lesions appear } \\
\text { partially atrophic and partially } \\
\text { pigmented } \\
\text { Multifocal chorioretinitis } \\
\text { Dense anterior chamber } \\
\text { inflammation } \\
\text { Vitritis } \\
\text { Peripheral retinal necrosis } \\
\text { Choroiditis } \\
\text { Submacular haemorrhages } \\
\text { Macular oedema } \\
\text { Neuroretinitis } \\
\text { Vaso-occlusive retinal vasculitis } \\
\text { Frosted branch angiitis } \\
\text { Exudative retinal detachment } \\
\text { Optic neuritis } \\
\text { Curvilinear clustering of whitish } \\
\text { yellow chorioretinal scars with a } \\
\text { 'target-like' appearance following the } \\
\text { course of the retinal nerve fibres }\end{array}$ & $\begin{array}{l}\text { Inner retinal oedema } \\
\text { in active inflammation } \\
\text { and retinal atrophy in } \\
\text { the late stage }^{67}\end{array}$ & $\begin{array}{l}\text { Active chorioretinal } \\
\text { lesions: early } \\
\text { hypofluorescence and } \\
\text { late staining } \\
\\
\text { Inactive lesions:central } \\
\text { hypofluorescence and } \\
\text { peripheral ring-like } \\
\text { hyperfluorescence } \\
\text { hy-69 }\end{array}$ & Supportive care ${ }^{68,69}$ \\
\hline Typhoid & $\begin{array}{c}\text { Decreased vision } \\
\text { RAPD } \\
\text { Colour vision } \\
\text { defect }\end{array}$ & $\begin{array}{c}\text { Disc pallor } \\
\text { Vasculitis } \\
\text { Multiple whitish fluffy areas of deep } \\
\text { retinitis } 16,74,76\end{array}$ & $\begin{array}{l}\text { Highly reflective and } \\
\text { disorganised inner } \\
\text { retinal layer } \\
\text { Serous retinal } \\
\text { detachment }\end{array}$ & & $\begin{array}{l}\text { Prednisolone }(1 \mathrm{mg} / \\
\mathrm{kg} \text { body weight/day) } \\
\text { Steroids tapered } \\
\text { over } 2 \text { months with } \\
\text { regular monitoring }\end{array}$ \\
\hline Rickettsiosis & Diminished vision & $\begin{array}{l}\text { Soft exudates } \\
\text { Retinal haemorrhages } 7,8,22 \\
\text { Retinal whitening }\end{array}$ & $\begin{array}{l}\text { Vitreous cells } \\
\text { Neurosensory } \\
\text { detachment }\end{array}$ & & $\begin{array}{l}\text { Oral doxycycline } \\
\text { Oral prednisolone } \\
7,8,22\end{array}$ \\
\hline
\end{tabular}

CME: cystoid macular oedema; ELM: external limiting membrane; FFA: fundus fluorescein angiography; OCT: optical cohorence tomography; ONL: outer nuclear layer; OPL: outer plexiform layer; RAPD: relative afferent pupillary defect; RD: retinal detachment. 
had a unilateral large retinitis patch with vascular sheathing, and relative afferent pupillary defect with no evidence of cerebral malaria. ${ }^{1}$ Table 2 summaries the clinical features seen in PFURS.

\section{Management}

Treatment of arbovirus infection (dengue fever, chikungunya, Zika virus, WNV, and yellow fever) is essentially symptomatic because there are currently no effective antiviral treatments. ${ }^{94}$

Steroids are the mainstay of treatment in patients who are persistently symptomatic and have poor vision as a result of ocular complications of PFURS.-19,14,15 In one case series, all patients with post fever retinitis were treated with oral prednisolone at $1 \mathrm{mg} / \mathrm{kg}$ body weight irrespective of aetiology, and the steroids were tapered based on clinical response over a period of 6 weeks; all patients had improvement in vision, despite the differences in aetiology.1,14 Oral doxycycline and/or acyclovir or valacyclovir can be started empirically while investigations are awaited. ${ }^{2}$ Other modalities of treatment are intravenous methylprednisolone, posterior sub-Tenon's injection, intravitreal triamcinolone, intravitreal anti-VEGF injections (bevacizumab or ranibizumab). ${ }^{2}$

However, a large number of patients have self-limiting disease and resolve spontaneously without any treatment. Some case reports and case series have documented successful conservative management, hence it is believed to be a self-limiting condition.,32 Even though spontaneous recovery is possible in post febrile neuroretinitis, steroids help in hastening the resolution of retinitis and improving the vision, thus decreasing the time to recovery. ${ }^{76}$ Whereas, another report by the present authors mentioned successful treatment of macular oedema and retinitis without steroids. ${ }^{77}$

\section{CONCLUSION}

Post fever retinitis of almost all aetiologies present with a similar morphological pattern because the condition manifests approximately 3 weeks after onset of fever and follows a preset natural course before resolution. These manifestations, which generally constitute inner retinitis at the posterior pole with or without optic nerve involvement, may be the result of a direct invasion by the pathogen or by indirect invasion mediated through immune-modulated mechanisms. It resolves in all cases without any relapses, but visual prognosis varies depending on macular ischaemic damage and optic nerve involvement. No specific treatment seems to be established based on the literature and patients may improve as a part of natural history of the disease process. However, some studies highlighted the need for a high index of suspicion by an ophthalmologist to diagnose this entity and for the early introduction of steroids for rapid improvement in symptoms and prevention of vision loss. Early referral to an ophthalmologist by the treating physician would result in a better functional outcome for the patients. This entity needs to be studied further to understand the detail of the natural history and histopathological and immunological aides. Further studies are needed to elucidate the mechanism of ophthalmic complications of viral, bacterial, and parasitic fevers.

\section{References}

1. Vishwanath $\mathrm{S}$ et al. Post-fever retinitis: a single center experience from South India. Int Ophthalmol. 2014;34:851-7.

2. Kawali $A$ et al. Epidemic retinitis. Ocul Immunol Inflamm. 2018:1-7.

3. Sivakumar R et al. Molecular diagnosis and ocular imaging of West Nile virus retinitis and neuroretinitis. Ophthalmology. 2013;120:1820-6.

4. Lalitha P et al. Ocular involvement associated with an epidemic outbreak of chikungunya virus infection. Am J
Ophthalmol. 2007;144:552-6.

5. Relhan $\mathrm{N}$ et al. A case of vasculitis, retinitis and macular neurosensory detachment presenting post typhoid fever. J Ophthalmic Inflamm Infect. 2014;4:23

6. Unnikrishnan S, Raju V. Ocular manifestations in mosquito-borne viral fevers. J Clin Ophthalmol Res. 2017;5:77-80

7. Balasundaram $M$ et al. Ocular manifestations of Rickettsia conorii in South India. Indian J Ophthalmol.
2018;66:1840-4.

8. Kawali A et al. Rickettsial retinitisan Indian perspective. J Ophthalmic Inflamm Infect. 2015;5:37.

9. Mahendradas $\mathrm{P}$ et al. Chikungunya and the eye: a review. J Ophthalmic Inflamm Infect. 2013;3:35.

10. Panchal B. Commentary: post fever retinitis and vasculitis: a morphological conundrum. Indian J Ophthalmol. 2018;66:1844.

11. Cunningham E et al. Acute multifocal 
retinitis. Am J Ophthalmol. 1997;123:347-57.

12. Su D et al. Prevalence of dengue maculopathy in patients hospitalized for dengue fever. Ophthalmology. 2007;114(9):1743-7.

13. Koundanya $\vee$ et al. Secondary dengue retinitis with associated occlusive retinal vasculitis. J Ophthalmic Inflamm Infect. 2019;9(1):7.

14. Mahendradas P et al. Ocular manifestations associated with chikungunya. Ophthalmology. 2008;115:287-91.

15. Mahesh $\mathrm{G}$ et al. A case of bilateral presumed chikungunya neuroretinitis. Indian J Ophthalmol. 2009;57:148-50.

16. Prabhushanker $M$ et al. Bilateral retinitis following typhoid fever. Int J Retin Vitr. 2017:3:10-2

17. Fusco R et al. Stellate maculopathy due to Salmonella typhi. A case report. Ophthalmologica. $1986 ; 192: 154-8$

18. Murthy $\mathrm{K}$ et al. Bilateral retinitis following chikungunya fever. Indian J Ophthalmol. 2008;56:329-31

19. Siqueira R et al. Ocular manifestations in dengue fever. Ocul Immunol Inflamm. 2004;12:323-7.

20. Lim W et al. Ocular manifestations of dengue fever. Ophthalmology. 2004;111:2057-64.

21. Sanjay S et al. Optic neuropathy associated with dengue fever. Eye. 2008;22:722-4

22. Shanmugam $M$ et al. Optical coherence tomography angiography features of retinitis post-rickettsial fever. Indian J Ophthalmol. 2019;67:297-300.

23. Haritoglou $\mathrm{C}$ et al. A tourist with dengue fever and visual loss. Lancet. 2002;360:1070.

24. Yamamoto $Y$ et al. Acute disseminated encephalomyelitis following dengue fever. J Infect Chemother. 2002;8:175-7.

25. Cruz-Villegas $\vee$ et al. Bilateral choroidal effusions associated with dengue fever. Retina. 2003:23:576-8.

26. Nainiwal $\mathrm{S}$ et al. Bilateral vitreous haemorrhage associated with dengue fever. Eye. 2005;19:1012-3.

27. Chlebicki MP et al. Retinal hemorrhages in 4 patients with dengue fever. Emerg Infect Dis. 2005;11:770-2.

28. Mehta S. Ocular lesions in severe dengue hemorrhagic fever (DHF). J Assoc Physicians India. 2005;53:656-

29. Preechawat P, Poonyathalang A Bilateral optic neuritis after dengue viral infection. J Neuroophthalmol. 2005;25:51-2
30. Menia NK et al. Fungal retinitis following influenza virus type $A$ (H1N1) infection. Indian J Ophthalmol. 2019:67(9):1483-4.

31. da Silva PAN et al. Arboviruses (chikungunya, dengue, and Zika) associated with ophthalmic changes: a focus on aqueous fluid and vitreous humor. Eur J Clin Microbiol Infect Dis. 2019;DOI:10.1007/s10096-019-037929.

32. Chan D et al. Ophthalmic complications of dengue. Emerg Infect Dis. 2006;12:285-9.

33. Khairallah $M$ et al. New infectious etiologies for posterior uveitis. Ophthalmic Res. 2013;49:66-72.

34. Yadav $\mathrm{H}$ et al. Dengue associated choroiditis: a rare entity. J Ophthalmic Inflamm Infect. 2017;7:14.

35. Tabbara K. Dengue retinochoroiditis. Ann Saudi Med. 2012;32:530-3.

36. Yip VC et al. Ophthalmic complications of dengue fever: a systematic review. Ophthalmol Ther. 2012;1(1):2.

37. Pang E, Loh $\mathrm{H}$. Current perspectives on dengue episode in Malaysia. Asian Pac J Trop Med. 2016:9(4):395-401.

38. Munk R et al. New associations of classic acute macular neuroretinopathy. Br J Ophthalmol. 2016;100:389-94

39. Aggarwal $\mathrm{K}$ et al. Optical coherence tomography angiography features of acute macular neuroretinopathy in dengue fever. Indian J Ophthalmol. 2017;65:1235-8

40. Juanarita J et al. Dengue related maculopathy and foveolitis. Asian Pac J Trop Biomed. 2012;2:755-6.

41. Akanda $\mathrm{M}$ et al. Multimodal imaging in dengue-fever-associated maculopathy. Ocul Immunol Inflamm. 2018;26:671-6.

42. Scripsema NK et al. Chikungunyaassociated uveitis and exudative retinal detachment: a case report. Retin Cases Brief Rep. 2015;9:352-6.

43. Martinez-Pulgarin F et al. Ophthalmologic aspects of chikungunya infection. Travel Med Infect Dis. 2016;14:451-7.

44. Khairallah M, Kahloun R. Ocula manifestations of emerging infectious diseases. Curr Opin Ophthalmol. 2013;24:574-80.

45. World Health Organization (WHO). Chikungunya and Dengue in the south west Indian Ocean. 2015 Available at: https://www.who.int/csr/ don/2006 03 17/en/. Last accessed: 03 June 2020

46. Borgherini $\mathrm{G}$ et al. Outbreak of chikungunya on Reunion Island: early clinical and laboratory features in 157 adult patients. Clin Infect Dis. 2007;44:1401-7.
47. Shukla J et al. Molecular detection and characterization of West Nile virus associated with multifocal retinitis in patients from southern India. Int J Infect Dis. 2012;16(1):e53-9.

48. Fontes BM. Zika virus-related hypertensive iridocyclitis. Arq Bras Oftalmol. 2016;79:63.

49. Miranda HA et al. Expanded spectrum of congenital ocular findings in microcephaly with presumed Zika infection. Ophthalmology. 2016;123:1788-94.

50. Ventura $C$ et al. Ophthalmological findings in infants with microcephaly and presumable intra-uterus Zika virus infection. Arq Bras Oftalmol. 2016;79:1-3.

51. Parke D et al. Serologically confirmed Zika-related unilatera acute maculopathy in an adult. Ophthalmology. 2016;123:2432-3.

52. Ventura $V$ et al. Zika virus in Brazil and macular atrophy in a child with microcephaly. Lancet. 2016;387:228.

53. Ventura $\vee$ et al. Zika: neurological and ocular findings in infant without microcephaly. Lancet. 2016;18:2502.

54. Freitas $B$ et al. Ocular findings in infants with microcephaly associated with presumed Zika virus congenital infection in Salvador, Brazil. JAMA Ophthalmol. 2016;134:529-35.

55. Ventura $V$ et al. Risk factors associated with the ophthalmoscopic findings identified in infants with presumed Zika virus congenital infection. JAMA Ophthalmol. 2016:134:912-8

56. de Moraes CG et al. Optic neuropathy and congenital glaucoma associated with probable Zika virus infection in Venezuelan patients. JMM Case Rep. 2018;5:jmmcr.0.005145.

57. Shantha $\mathrm{G}$ et al. Ebola virus disease and the eye. 2016;27:538-44.

58. Steptoe PJ et al. Multimodal imaging and spatial analysis of Ebola retinal lesions in 14 survivors of Ebola virus disease. JAMA Ophthalmol. 2018:136:689-93.

59. Steptoe PJ et al. Novel retinal lesion in Ebola survivors, Sierra Leone, 2016. Emerg Infect Dis. 2017;23:1102-9.

60. Shantha J et al. Ophthalmic manifestations and causes of vision impairment in Ebola virus disease survivors in Monrovia, Liberia. Ophthalmology. 2017:124:170-7.

61. Mattia JG et al. Early clinical sequelae of Ebola virus disease in Sierra Leone: a cross-sectional study. Lancet Infect Dis. 2016;16:331-8.

62. Kibadi $\mathrm{K}$ et al. Late ophthalmologic manifestations in survivors of the 1995 Ebola virus epidemic in Kikwit, Democratic Republic of the Congo. J Infect Dis. 1999;179:13-4.

63. Rabon $\mathrm{J}$ et al. Acute bilateral 
posterior angiopathy with influenza A viral infection. Am J Ophthalmol. 1987;103:289-93.

64. Faridi S et al. Pandemic 2009 influenza A H1N1 retinopathy. Can J Ophthalmol. 2010;45:286-7.

65. Ashfaq I et al. Acute macular neuroretinopathy associated with acute influenza virus infection. Ocul Immunol Inflamm. 2019;1-7. [Epub ahead of print].

66. Rifkin L, Schaal S. H1N1-associated acute retinitis. Ocul Immunol Inflamm. 2012;20:230-2.

67. Garg S, Jampol L. Systemic and intraocular manifestations of West Nile virus infection. Surv Ophthalmol. 2005;50:3-13.

68. Learned D et al. Multimodal imaging of West Nile virus chorioretinitis. Retina. 2014;34:2269-74.

69. Bains $\mathrm{S}$ et al. Vitritis and chorioretinitis in a patient with West Nile virus infection. Arch Ophthalmol. 2003;121:205-7.

70. Huang $\mathrm{C}$ et al. Clinical features of patients infected with 2019 novel coronavirus in Wuhan, China. Lancet. 2020;395(10223):497-506.

71. Marinho PM et al. Retinal findings in patients with COVID-19. Lancet. 2020;395(10237):1610.

72. Duke-Elder S, Perkins ES, Diseases of the Uveal Tract (1968), London: Kimpton.

73. Sinha M et al. Review of endogenous endophthalmitis caused by Salmonella species including delayed onset Salmonella typhi endophthalmitis. Semin Ophthalmol. 2012;27:94-8

74. Agarwal $M$ et al. Frosted branch angiitis in a patient with typhoid fever. Ocul Immunol Inflamm.
2018;26:776-8.

75. Dadia D et al. Salmonella typhi associated endogenous endophthalmitis : a case report and a review of literature. Ocul Immunol Inflamm. 2018;26:527-32.

76. Acharya P et al. Evaluation of posterior segment manifestations following typhoid fever-a clinical study. 2018;4:421-5.

77. Kawali A et al. Epidemic retinitis with macular edema -treatment outcome with and without steroids. Ocul Immunol Inflamm. 2020;1-5. [Epub ahead of print].

78. Khairallah $\mathrm{M}$ et al. Emergent infectious uveitis. Middle East Afr J Ophthalmol. 2009;16:225-38.

79. Khairallah $\mathrm{M}$ et al. Posterior segment manifestations of Rickettsia conorii infection. Ophthalmology. 2004:111:529-34.

80. Kurup $P$ et al. Spectral domain optical coherence tomography in the evaluation and management of infectious retinitis. Retina. 2014;34:2233-41

81. Beare $\mathrm{N}$ et al. Redefining cerebral malaria by including malaria retinopathy. Future Microbiol. 2011;6:349-55.

82. Teoh $\mathrm{S}$ et al. A re-look at ocular complications in dengue fever and dengue haemorrhagic fever. Dengue Bulletin. 2006;30:184

83. Teoh S et al. Optical coherence tomography patterns as predictors of visual outcome in dengue-related maculopathy. Retina. 2010;30:390-8.

84. Sudharshan S et al. Current approach in the diagnosis and management of posterior uveitis. Indian J Ophthalmol. 2010:58:29-43.

85. Agarwal A et al. Optical coherence tomography angiography features of bilateral retinopathy associated with chikungunya fever. Indian J Ophthalmol. 2018;66:142-5.

86. Agrawal $\mathrm{R}$ et al. Zika virus and eye. Ocul Immunol Inflamm. 2018;26(5):654-9.

87. de Paula et al. Zika virus and the eye. Curr Opin Ophthalmol. 2017;28:595-9.

88. Tiffany A et al. Ebola virus disease complications as experienced by survivors in Sierra Leone. Clin Infect Dis. 2016;62:1360-6.

89. Breker A et al. Vision loss caused by retinal and lateral geniculate nucleus infarction in H1N1 influenza. J Neuroophthalmol. 2015;35:265-9.

90. Cheung $Y$ et al. Bilateral vasoocclusive retinal vasculitis with h1n1 influenza A infection. Retin Cases Brief Rep. 2015;9:138-41.

91. Tao $Y$ et al. Two cases of exudative retinal detachment and uveitis following $\mathrm{H} 1 \mathrm{~N} 1$ influenza vaccination. Chin Med J (Engl). 2011;124:3838-40.

92. Lai $\mathrm{C}$ et al. Acute anterior uveitis and optic neuritis as ocular complications of influenza A Infection in an 11-yearold boy. J Pediatr Ophthalmol Strabismus. 2011:48:30-3.

93. Rubinov A et al. Bilateral optic neuritis after inactivated influenza vaccination. Isr Med Assoc J. 2012;14:705-7.

94. Merle $\mathrm{H}$ et al. Ocular manifestations of emerging arboviruses: dengue fever, chikungunya, Zika virus, West Nile virus, and yellow fever. J Fr Ophtalmol. 2018;41(6):e235-43. 